\title{
III. Fiatal Technológusok Fóruma
}

Szeged, 2020. december 14.

\section{In situ gélesedő meloxikám-humán szérum albumin nanorészecske formuláció fejlesztése nose-to-brain bevitel céljából}

Katona Gábor ${ }^{1}$, Szabóné Révész Piroska ${ }^{1}$, Balogh György Tibor ${ }^{2}$, Budai-Szúcs Mária ${ }^{1}$, Csóka lldikó ${ }^{1}$

${ }^{1}$ Szegedi Tudományegyetem, Gyógyszertechnológiai és Gyógyszerfelügyeleti Intézet

${ }^{2}$ Szegedi Tudományegyetem, Gyógyszerhatástani és Biofarmáciai Intézet

Számos neurodegeneratív betegségek kialakulásának korai stádiumában jelentős szerepet játszik a központi idegrendszer gyulladása. Ezt a tényt alapul véve a nem szteroid gyulladásgátlók (NSAID) intranazális úton a központi idegrendszerbe történő bejuttatása előnyös lehet a betegség progressziójának lassításában [1].

A humán szérum albumin (HSA) alkalmazásával előállítható olyan nano gyógyszerhordozó rendszer, amelyhez reverzibilisen NSAID köthető, növelve ezzel a hatóanyag biohasznosíthatóságot, valamint a stabilitását.

Munkánk során meloxikám (MEL) tartalmú HSA nanorészecskék fejlesztését tűztük ki célul, amely a beadást követően gyorsan, az orrüreg hőmérsékletén in situ gélesedik, megnövelve ezzel a formuláció tartózkodási idejét, valamint diffúzióját az orrnyálkahártyán. Gélesedő polimerként különböző koncentrációban poloxamer 407-et alkalmaztunk, intranazális bevitelhez optimalizálva. Kísérleteink magába foglalta módosított koacervációs eljárással előállított formulációk részecskekarakterisztika meghatározását, mukoadhéziós és reológiai tulajdonságainak vizsgálatait. A nose-to-brain alkalmazhatóság bizonyítására in vitro permeabilitási vizsgálatokat végeztünk RPMI 2560 humán orrnyálkahártya sejtvonalon, valamint vér-agy gát PAMPA modellen.

Eredményeink alátámasztották a beviteli kapu követelményeinek való megfelelést. A HSA-val stabil szerkezetú (98\%-os a HSA-MEL kötődés) nanorészecskék állíthatók elő, amelyek növelik a MEL látszólagos oldékonyságát, ugyanakkor kontrollált hatóanyag felszabadulást biztosítanak. A megfelelő koncentrációban alkalmazott poloxamer 407 beadást követően gyorsan gélesedett az orrüreg hőmérsékletén. Az optimalizált formuláció emelkedett MEL permeabilitást mutatott a humán orrnyálkahártya sejtvonalon.

Köszönetnyilvánítás: A kutatómunka az Innovációs és Technológiai Minisztérium ÚNKP-20-4 kódszámú Új Nemzeti Kiválóság Programjának a Nemzeti Kutatási, Fejlesztési és Innovációs Alapból finanszírozott szakmai támogatásával készült.

Irodalom

1. Tiozzo Fasiolo et al. J. Drug Target. 27, 984-994 (2019) 